УДК 368.0

DOI: https://doi.org/10.54929/pmt-issue2-2021-11

\title{
ВНУТРІШНІЙ КОНТРОЛЬ СТРАХОВИХ КОМПАНІЙ В СУЧАСНИХ УМОВАХ РОЗВИТКУ
}

\section{INTERNAL CONTROL OF INSURANCE COMPANIES IN MODERN CONDITIONS OF DEVELOPMENT}

\author{
Попова Л. В. \\ к.е.н., доцент, доцент кафедри публічних, \\ корпоративних фінансів та фінансового посередництва, \\ Чернівецький національний університет імені Юрія Федьковича \\ ORCID ID: 0000-0001-7015-5567 \\ Liubov Popova \\ $\mathrm{PhD}$ (Economics), Associate Professor, \\ Associate Professor of Department of Public, \\ Corporate Finances and Financial Mediation, \\ Yuriy Fedkovych Chernivtsi National University
}

У статті досліджено особливості організації системи внутрішнього контролю в діяльності страхових компаніях. Внутрішній контроль створюється з метою дотримання діяльності страховиків вимогам законодавства. Зосереджено увагу на тому, що внутрішній контроль страхової організації повинен поширюватися не тільки на страхову сферу, а й на сфреру діяльності, яка здійснюється в зв'язку зі страховою діяльністю, тобто в зв'язку з інвестиційною діяльністю страхової організації, оскільки розширилися можливості страховиків для активної участі на фондовому ринку і перетворення їх у важливих учасників інвестиційного процесу, якими страхові організації є майже в усьому світі. На нашу думку, введення служби внутрішнього контролю - це необхідність нинішнього етапу розвитку страхування в Україні. Розглянуто основні фоорми внутрішнього контролю в страхових організаціях, розкрито їх сутність. Досліджено основні напрями вдосконалення системи організації внутрішнього контролю в страхових організаціях. Зосереджено увагу на розвитку системи «Комплаєнс-контролю» в системі внутрішнього контролю страховиків. Ключові слова: внутрішній контроль, служба внутрішнього контролю, страхові компанії, страховий ринок, комплаєнс-контроль.

В статье исследованы особенности организации системы внутреннего контроля в страховых компаниях. Внутренний контроль создается в целях соблюдения деятельности страховщиков требованиям законодательства. Сосредоточено внимание на том, что внутренний контроль страховой организации должен распространяться не только на страховую сфреру, но и на сферу деятельности, осуществляемую в связи со страховой деятельностью, т.е. в связи с инвестиционной деятельностью страховой организации, поскольку расширились возможности страховщиков. активное участие на фоондовом рынке и превращение их в важных участников инвестиционного процесса, которыми страховые организации являются почти во всем мире. По нашему мнению, введение службы внутреннего контроля - это необходимость нынешнего этапа развития страхования в Украине. Рассмотрены основные формы внутреннего контроля в страховых организациях, раскрыта их сущность. Исследованы основные направления усовершенствования системы организации внутреннего контроля в страховых организациях. Сосредоточено внимание на развитии системы «Комплаенс-контроля» в системе внутреннего контроля страховщиков. Ключевые слова: внутренний контроль, служба внутреннего контроля, страховые компании, страховой рынок, комплаенс-контроль.

The article examines the features of the organization of the internal control system in the activities of insurance companies. Internal control is created in order to comply with the requirements of the legislation of insurers. Attention is focused on the fact that the internal control of the insurance organization should extend not only to the insurance sector, but also to the sphere of activity carried out in connection with insurance activities, in connection with the investment activities of the insurance organization. active participation in the stock market and their transformation into important participants in the investment process, which are insurance companies almost all over the world. The insurance sector of the financial system is a complex object for state regulation, due to the nature of insurance, which by its nature is risky. The probabilistic process of formation of insurance reserves and their further use to ensure insurance indemnity and payment of insurance amounts facilitates the possibility of certain uncontrolled transactions to legalize cash and insurance fraud, and the placement of own funds and borrowed insurance reserves in the relevant assets is not always a rational approach. In our opinion, the introduction of the internal control service is a necessity of the current stage of insurance development in Ukraine. The main forms of internal control in insurance compa- 
nies are considered, their essence is revealed. The main directions of improvement of the system of organization of internal control in insurance organizations are investigated. The focus is on the development of the Compliance Control system in the internal control system of insurers. Implementation of the Insurance Market Development Strategy is impossible without a modern internal control system built on an effective basis in cooperation with the economic security service of the insurance organization, implementation of a system of sales control and loss settlement, application of modern insurance technologies for creation and sale of insurance products business processes. Key words: internal control, internal control service, insurance companies, insurance market, compliance control.

Постановка проблеми. Питання розробки ефрективного механізму регулювання сфери страхування, найважливіше місце в якому відводиться системі внутрішнього контролю діяльності страхових організацій з кожним днем стає актуальнішим. Формування системи внутрішнього контролю в страхових організаціях продиктовано складністю фрінансових відносин, а також істотними змінами, що мають місце в сфрері страхування з року в рік.

Аналіз останніх досліджень і публікацій. Сучасні дослідження вітчизняних і зарубіжних авторів в області формування внутрішнього контролю, в т.ч. в страхових організаціях, представлені роботами Абдулина Є.Г.[1], Баранова А. Л.[2], Бобошко В.І.[3], Замбржицкая Є.С.[4], Землякова Ю.Д.[5], Мамаева І.Л.[6] та ін., в яких розглядається внутрішній контроль або з позицій внутрішнього аудиту, або стосовно до юридичних або до банківських ризиків, або як контроль ризиків, що виникають виключно в цілях протидії легалізації грошових доходів в банківській сфрері.

Виділення невирішених раніше частин загальної проблеми, котрим присвячується означена стаття. Внутрішньому контролю в страховій організації не приділяється належної уваги, оскільки до цих пір не визначено його місце в системі управління власними ризиками страхової організації, відсутня однакове розуміння внутрішнього контролю, не сформована система внутрішнього контролю в страховій організації. При цьому система внутрішнього контролю може стати дієвим інструментом, за допомогою якого можна підвищити ефективність контрольних процедур в рамках пріоритетних напрямків розвитку ринку страхування. Недолік методичних розробок в області формування системи внутрішнього контролю, її структурних елементів, методів та інструментів для страхових організацій визначає актуальність проблематики.

Формулювання цілей статті (постановка завдання). Мета роботи полягає в дослідженні принципів формування системи внутрішнього контролю в страхових організаціях в Україні на основі побудови системи «Комплаєнс-контролю».

Виклад основного матеріалу дослідження. Страховий сектор фрінансової системи $є$ складним об'єктом для державного регулювання, що обумовлено сутністю страхування, яке за своєю природою носить ризиковий характер. Ймо- вірнісний процес формування коштів страхових резервів і їх подальше використання для забезпечення страхового відшкодування та виплати страхових сум сприяє можливості здійснення певних безконтрольних операцій з метою легалізації грошових коштів та страхового шахрайства, а розміщення власних коштів і залучених коштів страхових резервів у відповідні активи не завжди відрізняється раціональним підходом.

Можна відзначити, що фрормування в процесі економічних відносин, що виникають між страхувальником і страховиком, страхового фонду, який має виключно грошову форму, володіє значним перерозподілом, створює інвестиційний потенціал для розвитку економіки, дає підставу вважати страхування невід'ємною частиною фрінансових відносин, які беруть участь у фрормуванні фрінансової системи, тобто страхування $€$ ланкою фрінансової системи.

Внутрішній контроль в страховій організації виступає як реалізація контрольної фрункції страхування.

По-перше, це пояснюється, перш за все, складністю фінансових відносин у сфрері страхування. Фінансові відносини страхової організації мають свої особливості, які знаходять прояви в існуванні двох незалежних оборотів грошових коштів і в наявності системи страхових резервів. Вони засновані на принципі акумулювання і наступного розподілу грошових потоків в залежності від статистики страхових випадків. Фінансові відносини як рух грошових коштів в страховій організації представляють собою два самостійних грошових потоки. Перший потік являє собою оборот коштів, пов'язаний з надходженням страхових платежів і виплатами за договорами страхування (забезпечення страхового захисту). Другий потік являє собою оборот коштів, пов'язаний з функціонуванням страхової організації, який визначається чинним законодавством, організаційно-правовою фрормою страховика, порядком розподілу прибутку, взаємовідносинами з бюджетом і т.д.[7].

Обіг коштів, що забезпечує страховий захист, має ризиковий, ймовірнісний характер руху. Він здійснюється в два етапи. На першому етапі формується і розподіляється страховий фонд, призначений на виплату страхового відшкодування. Однак виплати здійснюються тільки в разі настання страхової події. До тих пір нетто-премія резервується, утворюючи страховий фонд стра- 
ховика або страхові резерви. На другому етапі частина коштів страхового фонду використовується в комерційних цілях. Для отримання прибутку кошти страхових резервів інвестуються в відповідні активи.

По-друге, внутрішній контроль в страхових організаціях пов'язаний з реалізацією контрольної функції страхування, яка проявляється через контроль за фрормуванням коштів страхових резервів - основи діяльності страхової організації.

По-третє, внутрішній контроль в страхових організаціях пов'язаний з реалізацією контрольної функції страхування, яка проявляється через контроль за фрормуванням власних коштів страхової організації. Власний капітал страхових організацій повинен бути сформований в необхідному обсязі, повинен бути реальним, тобто грошовим, оплаченим.

По-четверте, внутрішній контроль в страхових організаціях пов'язаний з реалізацією контрольної функції страхування, яка проявляється через контроль за інвестиційною діяльністю страхової організації. Кошти страхових резервів і власні кошти страхові організації інвестують в відповідні активи згідно з законодавством. Контроль за виконанням вимог даних нормативних документів - одна зі сторін внутрішнього контролю в страхових організаціях.

По-п'яте, внутрішній контроль в страхових організаціях пов'язаний з реалізацією контрольної функції страхування, яка проявляється через контроль за використанням як власних коштів, так і залучених коштів страхових резервів в результаті здійснення виплат за договорами страхування при настанні страхових випадків $[8,39]$.

При розгляді поняття «внутрішній контроль» зазвичай керуються кількома підходами. По-перше, внутрішній контроль розглядається як напрямок діяльності будь-якої організації, в тому числі і страхової організації. Керівництво організації, виконуючи функції з управління діяльності, здійснює контроль цієї діяльності, тобто виконує контрольну функцію з метою забезпечення безперервності матеріально-речового і фрінансового оборотів. В даному випадку потрібно говорити про створену в організації службу внутрішнього контролю або навіть системи внутрішнього контролю (СВК), яка здійснює моніторинг господарської діяльності. В рамках служби внутрішнього контролю може здійснюватися внутрішній аудит діяльності організації, який зазвичай прив'язаний до здійснення аналізу бухгалтерської та фрінансової звітності організації. При цьому підході поняття «внутрішній контроль» ширше за поняття «внутрішній аудит» навіть тому, що внутрішній контроль, також як і фрінансовий контроль, здійснюється постійно протягом усього періоду фрункціонування організації, а внутрішній аудит являє собою одноразовий захід, який періодично проводиться за вказівкою керівництва організації.

Другий підхід зазвичай заснований на ототожненні понять «внутрішній контроль» і «внутрішній аудит». "Система внутрішнього контролю являє собою сукупність організаційних заходів, методик і процедур, що використовує управлінський персонал як засоби для впорядкованого і ефективного ведення фрінансово-господарської діяльності, забезпечення збереження активів, виявлення, виправлення і запобігання помилок і спотворення інформації, а також своєчасної підготовки достовірної фрінансової (бухгалтерської) звітності». 3 цього визначення випливає, що до об'єктів внутрішнього контролю відносяться: бухгалтерська звітність; статті бухгалтерської звітності; рахунки бухгалтерського обліку; документація економічного суб'єкта; економічні показники; господарські операції; економічні дії і події; цикл діяльності організації.

Таким чином, під внутрішнім контролем розуміється проведення внутрішнього аудиту. Іншими словами, внутрішній аудит бере на себе функції внутрішнього контролю і навіть замінює його. Це відбувається тоді, коли організація відрізняється низьким рівнем розвитку менеджменту та персоналу компанії.

Третій підхід пов'язаний з поданням внутрішнього контролю як елемента ризикоорієнтованого нагляду, що дозволяє страховим організаціям бачити власні ризики і контролювати свою фрінансову стійкість. Орган контролю в міру необхідності зможе запрошувати інформацію з оцінки ризиків страховиків - це стане певною альтернативою введення щоденної звітності для страхових організацій (зараз вона надається раз в три місяці). Однак в банківському секторі в ряді випадків навіть така система внутрішнього контролю не спрацьовує.

Аналізуючи дані підходи можна відзначити, що всі вони носять дещо обмежений характер. Разом з тим, можна виділити дві загальних моделі, що відображають дані підходи зміст поняття внутрішнього контролю. Перша модель заснована на ідеї повного регулювання діяльності страхової організації (повний внутрішній контроль), друга модель представлена внутрішнім контролем, орієнтованого на ризик.

Для реалізації моделі повного внутрішнього контролю необхідно розробити стандарти діяльності системи, провести аналіз і порівняти досягнуті результати з встановленими стандартами, а, в разі невідповідності фрактичних результатів встановленим стандартам, провести коригування процесів управління. У цьому випадку внутрішній контроль виступає як перевірка здійснення прийнятих рішень і дотримання встановлених 
обмежень. Таке визначення підкреслює функціональне призначення контролю, виникнення його на стадії прийняття рішення в процесі його виконання. 3 іншого боку, внутрішній контроль визначається як виявлення відповідності дійсного стану або поведінки контрольованого «наміченим», тобто підкреслюється спрямованість контролю.

Формування системи внутрішнього контролю страхових організацій продиктовано складністю фінансових відносин, а також істотними змінами, що мають місце в сорері страхування, пов'язаними, перш за все, з складними політичними та економічними умовами розвитку. Потреба враховувати об'єктивні реалії сьогоднішнього дня, обумовлена необхідністю ефективного використання фрінансових ресурсів страхових організацій. В даному випадку під ефективним використанням фінансових ресурсів розуміється їх достатність для виконання зобов'язань перед страхувальником і здійснення поточної діяльності. Тому необхідність формування системи внутрішнього контролю страхових організацій, як видається, обумовлено дією наступних основних фракторів:

- складністю фрінансових відносин у сфрері страхування;

- загальним розвитком вітчизняного ринку страхування;

- підвищенням мінімальної величини статутного капіталу страхових організацій;

- посиленням присутності іноземних страхових компаній на українському ринку страхування;

- введенням нових вимог, що пред'являються до активів, що приймаються в покриття як власних коштів, так і коштів страхових резервів страхових організацій;

- врегулюванням збитків, в тому числі в зв'язку зі страховим шахрайством.

Введення страховиком внутрішнього контролю - давня світова практика. Так, в окремих компаніях, акціонерами яких виступають іноземні інвестори, неможливо ведення бізнесу без належної системи внутрішнього контролю. Це реалізується через комплексну систему заходів, в тому числі через створення спеціалізованих підрозділів: внутрішній аудит, підрозділ, що відповідає за дотримання норм чинного законодавства (Compliance - Комплаенс), управління ризику.

Термін Compliance став складовою частиною західного бізнес-лексикону з середини 1990-х років. «У міжнародній бізнес-практиці Compliance (від англ. - дотримання законодавчих вимог, відповідність стандартам) - це система, спрямована на захист акціонерів, керівників та інших співробітників компанії від можливих порушень норм і правил ведення бізнесу» [9,52]. Вона спрямована на мінімізацію правових позовів і санкцій, ви- роблення заходів щодо запобігання репутаційних ризиків і в цілому збільшення вартості компанії для інвесторів. Реалізація функції Compliance передбачає взаємодію з менеджментом і співробітниками компанії з метою виявлення, оцінки та запобігання compliance-ризиків. Compliance - це невід'ємний елемент діяльності більшості великих міжнародних практик. Compliance $є$ однією з найважливіших частин системи внутрішнього контролю страхових організацій.

В даний час система «Комплаєнс» в Україні поки ще маловідома і не регулюється спеціальним законодавством. Однак в ряді страхових організацій вона вже успішно діє. Окремі страхові організації ввели або намагаються ввести системи ефективного «Комплаєнс-контролю», як самостійного напрямку в системі внутрішнього контролю страхової організації. Це стосується, перш за все, тих страхових організацій, які мають високу частку участі іноземного капіталу в структурі власного капіталу страхової організації.

Наприклад, система «Комплаєнс» в СГ «ТАС» складається з декількох напрямків, кожний з яких регулюється внутрішніми нормативними документами: антикорупційна політика (Anticorruption), політика протидії легалізації (відмиванню) доходів, одержаних злочинним шляхом (Anti-money-laundering), політика щодо протидії внутрішньому шахрайству (Anti-Fraud), регламент управління конфлліктом інтересів (Confict of Interests).

Так, наприклад, метою антикорупційної політики $€$ визначення основних правил, стандартів і принципів, спрямованих на попередження, запобігання та встановлення фрактів корупції і хабарництва.

Області високих корупційних ризиків включають в себе:

- ділові ласку;

- наймання представників;

- відрахування на політичні потреби;

- відрахування на благодійність;

- спільні підприємства і угоди про надання послуг;

- винагорода за спрощення формальностей.

Контроль за дотриманням політики покладено, перш за все, на співробітників компанії: кожен може повідомити про скоєння порушення.

Відповідно до політики з протидії внутрішньому шахрайству внутрішнє шахрайство визначається як будь-яке незаконне діяння, що характеризується обманом, приховуванням фрактів або зловживанням довірою. Внутрішнє шахрайство включає в себе також і помилкове уявлення / перекручування фрактів у фрінансовій звітності, а також шахрайство на користь компанії.

Принципи протидії внутрішньому шахрайству: 
- відповідальність керівництва;

- участь працівників в боротьбі з внутрішнім шахрайством;

- кадрова політика;

- принцип абсолютної нетерпимості.

Оцінка ризиків внутрішнього шахрайства, будучи одним з найважливіших елементів політики з протидії внутрішньому шахрайству, включає в себе ідентифікацію ризиків, оцінку ступеня і частоти ризиків.

Одним 3 найважливіших умов успішного і ефективного виконання працівниками своїх посадових обов'язків $€$ відсутність протиріч між приватними інтересами працівника і інтересами компанії, а при наявності таких протиріч - їх своєчасне розкриття і врегулювання. 3 метою виключення конфлікту інтересів між приватними інтересами працівника і інтересами компанії діє система управління конфлліктом інтересів, яка заснована на наступних принципах:

- обов'язкове розкриття відомостей про реальний або потенційний конфрлікт інтересів;

- індивідуальний розгляд, оцінка серйозності ризиків для компанії і врегулювання конфллікту інтересів;

- конфріденційність процесу розкриття відомостей про конфрлікт інтересів та його врегулювання;

- дотримання балансу інтересів компанії та працівника при врегулюванні конфрлікту інтересів;

- захист працівника від переслідування у зв'язку з конфрліктом інтересів, який був своєчасно розкритий працівником $[5,25]$.

При цьому компанія гарантує, що жоден працівник не буде притягнутий до відповідальності і не буде відчувати інших несприятливих наслідків за ініціативою компанії в зв'язку з дотриманням вимог управління конфлліктом інтересів і повідомленням про потенційні порушення.

Управління системою «Комплаєнс» здійснюється централізовано Департаментом внутрішнього контролю і координації корпоративних і регуляторних процедур (Compliance), який функціонує в складі Центру корпоративного управління компанії.

Система «Комплаенс» в ПрАТ УПСК також складається з декількох напрямків, кожен з яких регулюється внутрішніми нормативними документами: управління бізнесом, зловживання становищем на ринку, правовідносини з регуляторами, ліцензійні вимоги, фрінансові порушення, які включають протидії відмиванню доходів, одержаних злочинним шляхом, антикорупційна діяльність, незаконне володіння інформацією, економічні санкції, економічна безпека.

Ризики, обумовлені фрінансовою стійкістю, рівнем ліквідності, оподаткуванням, вимога- ми до бухгалтерської звітності, до фрормування страхових резервів, інфрормаційною безпекою, положенням про охорону здоров'я, знаходяться під контролем інших служб страхової організації: фрінансового, юридичного департаментів, департаментом по персоналу, з інформаційних технологій, службою з проведення актуарних розрахунків (розрахунків страхових тарифів). Нам видається, що і ці ризики повинні потрапляти під систему контролю «Комплаенс», оскільки вони можуть вплинути на фінансову безпеку, а значить і на економічну безпеку страхової організації, яка охоплена системою «Комплаєнс».

Разом 3 тим, ефективний «Комплаєнс-контроль», дозволяє, перш за все, встановити контроль за юридичними ризиками, пов'язаними 3 регулюванням страхової діяльності. Виникнення і зростання рівня таких ризиків можуть викликати значні фрінансові втрати внаслідок введення санкцій проти страхових організацій, збільшення вимог до капіталу. Також страхові організації мають можливість ефективно запобігати виникненню ризику втрати репутації, пов'язаного 3 недобросовісним виконанням співробітниками правил дотримання норм ділової етики. Крім того, система «Комплаенс-контроль» дозволяє забезпечити страховим організаціям контроль за ризиками, пов'язаними з формуванням і розміщенням власних коштів і коштів страхових резервів страхової організації.

Система «Комплаєнс-контроль» повинна включати систему заходів, в тому числі політику та процедуру по відстеженню руху коштів з метою запобігання операцій по легалізації грошових коштів, моніторинг комплаенс-ризиків за всіма напрямами діяльності страхових організацій (страхова, інвестиційна, нестрахова), її операціями, продуктами, послугами і територіальними підрозділами.

Таким чином, на нашу думку, «Комплаєнс-контроль» можна розглядати як інструмент організації внутрішнього контролю страхових організацій, як самостійний напрям в системі внутрішнього контролю страхової організації і як метод боротьби з правопорушеннями в цілях забезпечення фінансової безпеки сфрери страхування.

Відмінною особливістю системи «Комплаенс», на нашу думку, є також і те, що ця система дозволяє об'єктивно підійти до оцінки діяльності керівників страхової організації. Саме вони $\epsilon$ ініціаторами створення системи внутрішнього контролю страхової організації, але саме вони і не схильні до контролю з боку цієї системи. Іншими словами особливістю внутрішнього контролю $€$ приналежність контролюючого суб'єкта підконтрольній системі. Типовим прикладом $є$ ревізійний відділ організації, який $є$ ії̈ ж струк- 
турним підрозділом, а, отже, підпорядковується керівництву організації. Система «Комплаенс» дозволяє акцентувати увагу на оцінку дій вищого керівництва і власників страхової організації, а не тільки в більшій мірі контролювати дії працівників нижчого рангу.

Таким чином, система «Комплаєнс-контроль» повинна будуватися на наступних принципах:

1. Комплексний підхід. Система «Комплаєнс-контроль» дає можливість здійснювати контроль фрінансових ризиків за всіма напрямами діяльності страхової організації; ризиків, пов'язаних з порушенням законодавства і обумовлених шахрайськими операціями, легалізацією (відмиванням) злочинних доходів, перекладом капіталів за кордон, відходом від податків; ризиків, пов'язаних з втратою репутації, викликаної недобросовісним дотриманням співробітниками страхової організації правил і норм ділової етики; юридичними ризиками, пов'язаними з регулюванням страхової діяльності.

2. Об'єктивність оцінки діяльності. Керівники страхової організації зазвичай створюють таку систему внутрішнього контролю, при якій вони самі виявляються поза сферою розгляду і критики. Система ж «Комплаенс-контроль», орієнтована на підвищення ефрективності в цілому, дозволяє більш об'єктивно підійти до оцінки діяльності керівників страхової організації. «Комплаенс-контроль» підвищує дієвість системи внутрішнього контролю внаслідок оцінки діяльності контрольованих осіб незалежно від їх статусу в організації.

3. Універсальність застосування. Систему «Комплаєнс-контроль» можна вважати стандартною, що може застосовуватися всіма страховими організаціями. При її впровадженні необхідно розробити комплаенс-програми, комплаенс-стратегії і комплаенс-плани.

4. Високий статус в організації та компетентність. Виконання комплаенс-фрункцій може зустріти опір з боку окремих підрозділів страхової організації і частини керівництва, оскільки воно може піти врозріз з інтересами бізнесу (наприклад, ініційоване службою комплаєнс-контролю переривання контактів з партнерами і клієнтами з сумнівною репутацією, заборона на проведення деяких фрінансових операцій і т. п.). Тому організаційну структуру необхідно вибудовувати таким чином, щоб служба комплаенс-контролю була наділена необхідними повноваженнями, а іiї персоналу надати високий статус в ієрархії організації і права незалежного прийняття рішень.

Співробітники, відповідальні за комплаенс-контроль, повинні володіти необхідним досвідом, високим рівнем професійної підготовки і особистісними якостями, що дозволяють здійснювати ефективний контроль в своїй організації.
5. Адекватність сфери застосування. В процесі впровадження і здійснення комплаенс-контролю необхідно мати на увазі, що $є$ певна грань, після якої контрольна фуннція не тільки мінімізує ризики, але і істотно обмежує основну діяльність страхової організації (відомо, що нульові ризики досяжні лише при повній відсутності будь-якої економічної діяльності). Тому в діяльності організації необхідно визначити області мінімальної і максимальної чутливості до комплаенс-ризиків і відповідного «гальмування» діяльності організації. Адекватне розмежування цих областей, без зміщення в ту чи іншу сторону, забезпечує найбільш ефрективну організацію робочого процесу, без шкоди для задач організації в цілому і при мінімізації величини ризику. Для коригування цієї межі організації необхідно відстежувати зовнішнє середовище свого бізнесу - тенденції ринку, зміни законодавства, поява інновацій і т.д. $[10,135]$.

В цілому «Комплаєнс-контроль» сприяє зміцненню фрінансової стійкості і фрінансової безпеки страхових організацій.

Посилення ролі комплаєнс-контролю в страхових організаціях і розробка у відповідність 3 комплаєнс-контролем і з урахуванням специфіки кожної страхової організації комплаєнс-програми, комплаенс-стратегії і комплаенс-плану дозволить, на наш погляд, ефективніше протистояти різного роду ризикам, особливо в рамках реалізації Закону «Про протидію легалізації (відмиванню) доходів, одержаних злочинним шляхом та фрінансуванню тероризму».

Разом $з$ тим, необхідно відзначити наступне. Світова практика заснована на зрощуванні і об'єднанні інститутів внутрішнього аудиту та внутрішнього контролю. Стосовно до українських реалій на першому етапі будуть введені інститути внутрішнього аудиту та внутрішнього контролю. Наглядовий орган передбачає, що це великий крок вперед в зв'язку з повною відсутністю даних інститутів. На другому етапі буде створено об'єднаний інститут внутрішнього аудиту і контролю. При цьому дуже важливо враховувати обсяги бізнесу страхових організацій, що суперечить світовій практиці. Поділ даних видів контролю має місце тільки в великих організаціях, де вже $\epsilon$ налагоджений ризик-менеджмент, в інших же організаціях відбувається їх поєднання.

Об'єднання інститутів внутрішнього аудиту та внутрішнього контролю в майбутньому вимагатиме створення, на наш погляд, і більш гнучкої системи внутрішнього контролю в цілому на базі системи «Комплаєнс-контроль». При цьому необхідний комплексний підхід. В цілому, необхідно створити повноцінну концепцію боротьби з правопорушеннями в сфрері страхування, яка 
носила б системний характер, грунтувалася б на сукупності базових принципів, включала б оформлені стратегії і управлінські моделі для окремих видів страхових випадків.

Висновки. Реалізація Стратегії розвитку ринку страхування неможлива без сучасної системи внутрішнього контролю, побудованої на ефективній основі при взаємодії зі службою економічної безпеки страхової організації, впровадженні системи контролю за рівнем продажів і врегулювання збитків, застосування сучасних страхових технологій створення і реалізації страхових продуктів, що включають системний реінжиніринг всіх бізнес-процесів.

Наявність або відсутність такої системи комплаєнс в страхових організаціях, сформованої з урахуванням міжнародної практики, безпосеред- ньо пов'язане з якістю інвестиційного клімату та інвестиційним потенціалом кожного економічного суб'єкта. Ситуація ускладнюється тим, що в даний час відсутня необхідна кількість професійно підготовлених з урахуванням міжнародних вимог фрахівців в області внутрішнього контролю. На ринку праці практично немає фрахівців, які зможуть поєднувати фрункції внутрішнього аудитора і внутрішнього контролера. Іншими словами, в вищих навчальних закладах необхідно готувати фахівців, які поєднували б знання в області перевірки дотримання бізнес-процесів і фрінансового аудиту з навичками в області оперативно-розшукової роботи. Це складне завдання, але рішення цієї проблеми необхідно знайти в найкоротші терміни.

\section{БІБЛІОГРАФІЧНИЙ СПИСОК:}

1. Абдулина Е.Г. Основы классификации рисков и контрольных действий при построении систем внутреннего контроля в страховых компаниях на примере департамента андеррайтинга. Экономика и предпринимательство. 2015. (12-1). С.532-536.

2. Баранов А. Л. Ідентифрікація страхових ризиків та її значення для управління страховим портфелем. Фінанси України. 2011. № 8. С. 115-124.

3. Бобошко В.И. Внутренний контроль как элемент обеспечения фринансовой безопасности страховых организаций. Инновационное развитие экономики. 2017. (3). С.206-209.

4. Замбржицкая Е.С. Оценка надежности системы внутреннего контроля страховой компании на уровне бизнес-процессов на примере департамента андеррайтинга. Молодой ученый. 2016. (17). С.383-389.

5. Земляков Ю.Д., Мамаева И.Л. О внутреннем контроле в страховых организациях. Вестник Международной академии системных исследований. Инфоорматика, экология, экономика. 2016. (2). С.23-26.

6. Ишкинина Э.Н. Система внутреннего контроля в страховой организации. Символ науки. 2016. (12).С.104107.

7. Мейланова М. ЦБ разработал требования к внутреннему контролю страховщиков. Экономика и жизнь. 2016. URL: https://www.eg-online.ru/article/305983 (дата обращения: 10.10.2021).

8. Мячин Н.В., Горшкова Е.В. Система внутреннего контроля как средство управления операционными рисками страховой организации. Страховое дело. 2016. (10). С.38-41.

9. Пешкова Т.Ю. Управление рисками, внутренний контроль и внутренний аудит страховых организаций в системе страхового надзора Канады. Финансовая аналитика: проблемы и решения. 2013. № 42(180). С.4856.

10. Турсунова Н.А., Прокофьева В.Ю. Оценка систем внутреннего контроля и внутреннего аудита страховой компании. Развитие науки и образования в современном мире. 2017. (2). С.136-138.

\section{REFERENCES:}

1. Abdulina, E.G. (2015). Osnovy klasyfikatcii riskov i kontrolnyh deistvii pri postroenii system vnutrennego kontrolia $v$ strahovyh kompaniah na primere departamenta anderraitenga [Fundamentals of risk classification and control actions when building internal control systems in insurance companies on the example of the underwriting department]. Ekonomika i predprinimatelstvo - Economics and Entrepreneurship. (12-1). 532-536. (in Russian).

2. Baranov, A.L. (2011). Identyfikatcia strahovyh ryzykiv ta ii znachennia dlia upravlinnia strahovym portfelem [Identification of insurance risks and significance for the management of the insurance portfolio]. Finansy Ukrainy - Finance of Ukraine. 8. 115-124. (in Ukrainian).

3. Boboshko, V.I. (2017). Vnutrennii control kak element obespechenia finansovoi bezopasnosti strahovyh organizatcii [Internal control as an element of ensuring the financial security of insurance organizations]. Innovatcionnoe razvitie ekonomiki - Innovative development of the economy. 3. 206-209. (in Russian).

4. Zambrzgytckaia, E.S. (2016). Otcenka nadiozhosti sistemy vnutrennego kontrolia strahovoi kompanii na urovne biznes-protcessov na primere departamenta anderraitenga [Assessment of the reliability of the internal control system of an insurance company at the level of business processes using the example of the underwriting department]. Molodoi uchenyi - Young scientist. 17. 383-389. (in Russian).

5. Zemliakov, U.D., Mamaeva, I.L. (2016). O vnutrennem kontrole v strahovyh organizatciiah [Internal control in insurance organizations]. Vestnik Mezgdunarodnoi akademii sistemnyh issledovanii. Informatika, ekologia, ekonomika - Bulletin of the International Academy of Systems Research. Informatics, ecology, economics. 2. 23-26. (in Russian). 
6. Ishkinina, E.N. (2016). Sisitema vnetrennego kontrolia v strahovoi organizatcii [Internal control system in an insurance company]. Simvol nauki - Science symbol. 12. 104-107. (in Russian).

7. Meilanova, M. (2016). TCB razrabotal trebovaniia k vnutrennemu kontroliu strahovshikov [The Central Bank has developed requirements for the internal control of insurers]. Ekonomika i zgizn - Economy and life. (in Russian). Access mode: https://www.eg-online.ru/article/305983 (accessed 10 October 2021).

8. Miachyn, N.V., Gorshkova, E.V. (2016). Sistema vnutrennego kontrolia kak sredstvo upravleniia operaycionnymi riskami strahovoi organizatcii [Internal control system as a means of managing operational risks of an insurance company]. Strahovoe delo - Insurance business. 10. 38-41.

9. Peshkova, T.U. (2013) Upravlenie riskami, vnutrennii control i vnutrennii audit strahovyh organizatcii v sisteme strahovogo nadzora Kanady [Risk management, internal control and internal audit of insurance companies in the insurance supervision system of Canada]. Finansovaia analitika: problem i resheniia - Financial analytics: problems and solutions. 42(180). 48-56. (in Russian).

10. Tursunova, N.A., Prokopheva, V.U. (2017). Otcenka system vnutrennego kontrolia i vnutrennego audita strahovoi kompanii [Assessment of internal control and internal audit systems of an insurance company]. Razvitie nauki i obrazovaniia v sovremennom mire - Development of science and education in the modern world. 2. 136-138. (in Russian). 